\title{
An Empirical Investigation of the Underpricing of Initial Public Offerings in the Chittagong Stock Exchange
}

\author{
Md. Aminul Islam (Corresponding author) \\ Lecturer, School of Business Innovation and Technopreneurship \\ University Malaysia Perlis, Malaysia \\ E-mail: amin_shanto@yahoo.com \\ Ruhani Ali \\ Professor, Graduate School of Business \\ Universiti Sains Malaysia \\ E-mail: ruhani@usm.my \\ Zamri Ahmad \\ Associate Professor and Deputy Dean, School of Management \\ Universiti Sains Malaysia \\ E-mail: zahmad@usm.my
}

\begin{abstract}
This study analyzes the levels of underpricing in IPOs and its determinants of the Chittagong Stock Exchange (CSE). The degree of underpricing in the Bangladesh capital market is rather high compared to that of other Asian and advanced stock markets. Key trends in the levels of underpricing and overpricing are highlighted on a year to year, and industry to industry bases. The overall level of underpricing at the Chittagong Stock Exchange was 480.72\% with a standard deviation of 1217.25 . Out of the 191 companies that were listed in the years 1995 to 2005,173 $(90.57 \%)$ IPOs were found to be underpriced, $16(8.37 \%)$ overpriced while only 2 were accurately priced. The overall level of overpricing was $17.87 \%$ with a standard deviation of 14.14 . Regression analysis shows that age of the firm, and size of the company is positively related to the degree of underpricing. The industry type and offer size are found to be negatively related to the degree of underpricing. However the timing of offer was found to have no significant influence on the degree of underpricing of IPOs in the Chittagong Stock Exchange.
\end{abstract}

Keywords: Initial public offering, Underpricing, Determinants of underpricing, Chittagong Stock Exchange

\section{Introduction}

Initial public offering (IPO) underpricing, or high IPO return is a common phenomenon to most stock markets, regardless of whether these markets are in developed or emerging economies (Ritter et al., 1984). A common perception is that underpricing of IPOs is a contradiction to market efficiency and may worsen emerging firms trying to raise capital for expansion. This perception has spawned an extensive literature attempting to explain this apparent financial anomaly. A number of IPOs underpricing have been put forth and tested using the data of various stock markets. According to Ritter (1984), IPO underpricing occurs depending on the period a firm chooses to go public. Rock's model of "underpricing” as an expected equilibrium results are supported by Beaty and Ritter (1986), who, in turn, proposed that underpricing is related to ex ante uncertainty. As a follow up to IPOs underpricing, McDonald and Fisher (1972), Reilly (1978), Dawson (1987), Yong (1996), Haque and Musa (2002), Lowry et al. (2006), and Taufil (2007) maintained that there are significant returns to the investors in the short run. Although hundreds of empirical studies have been carried out and theoretical literature written to enhance people's knowledge towards these issues; yet it is arduous for people to clearly understand the various issues related to IPOs especially with different types of equities in different industries and in different markets.

Previous studies indicated that underpricing occurs across a number of different times and samples (McGuiness, 1992). The degree of underpricing varies from one issue to another. Studies on Malaysian new stock offers (e.g., Dawson, 1987; Yong, 1991, 1996; Sufar, 1987; Ismail et al., 1993; Yeap, 2006; Taufil, 2007) indicate significant returns received by investors at the time of initial listing. Studies on Bangladesh new stock offers (e.g., Islam, 1999; Haque \& Musa, 2002) indicate existence of higher degree of underpricing. The analysis of the excess returns after 
trading began also reveals that the price adjusts rapidly to the underpricing of the initial offers. This result is consistent regardless of whether the amount of increase registered at the opening day is high or low.

The degree of underpricing in Bangladesh capital market is rather higher compared to that of other Asian and advanced stock markets. Islam (1999) documented that the average initial returns is 116.01 percent with a standard deviation of 261.94 percent during 1994-1999. Hoque and Musa (2002) find that between 1994 and 2001 the IPOs of Dhaka Stock Exchange was largely underpriced at 285.21 percent. For the same time period, the degree of underpricing in Malaysia was $46.44 \%$ (Yeap, 2006), in Singapore and Turkey $31.4 \%$ and $13.6 \%$, respectively (Laughran et al., 2000) and in the US market 22\% (Lowry et al., 2006).

Bloomberg (Oct.9, 2007) reported that the Dhaka Stock Exchange Index is at a 10-year high, up 66 percent this year, making it Asia's top performer after China. Citigroup Inc., JPMorgan Chase \& Co. and Merrill Lynch \& Co. are betting Bangladesh capital market may be the next Asian success story. September 2007, New York-based Citigroup, the largest U.S. bank, became the first foreign lender to get a license to offer merchant- banking and investment-banking services. JPMorgan named Bangladesh one of the "Frontier Five" markets worth investigating in an April 4 note, along with Kazakhstan, Kenya, Nigeria and Vietnam.

The purpose of this study is to investigate the price behavior of initial public offerings of the Chittagong Stock Exchange during the period of 1995-2005. This study will provide an insight for the future investors regarding the types of IPOs that is best to invest in as in-depth analysis of the issue of underpricing and the stock price behavior shall be explored. Different levels of underpricing observed in different countries show that there might be some unique features in each country and these features might affect underpricing. Institutional differences in pricing and allocation of shares play an important role in explaining the degree of underpricing (Loughran et al., 1994). Bangladesh capital market is unique with an interesting characteristic which IPOs are allowed for dual listing. It is found that $95 \%$ IPOs that are listed with CSE are also listed at DSE. Therefore it will be interesting to find out the extent of underpricing and its determinants in Bangladesh capital market.

\section{Bangladesh capital market:- an overview}

Bangladesh capital market is quite small compared to other regional markets and the size of its economy. Though generally a capital market has two prongs, the stock market and the debt market, Bangladesh market has only stock market in active operation, as a debt market is still in initial stage.

Among over 40,000 small and medium companies only 310 have become listed till April 30, 2007, of which 33 have been de-listed in the past 15 years. Though the governments tried to attract the growing private companies to turn their enterprises into public limited and get listed to reap benefits and avail incentives offered time to time, on average only 10 companies have joined the market each year.

Though industrialization has picked pace in Bangladesh almost three decades back, capital market has failed to attract the entrepreneurs as the key source of capital, which has usually been occupied by the banking system since beginning. That is why Bangladesh capital market has the lowest market capital as percentage of GDP in the region as well as other similar sized economies, while its neighbouring country, India, sharing almost the same industrial history, has the highest. (Table 1)

Bangladesh has two Stock Exchanges, Dhaka Stock Exchange (DSE), established in 1954 where trading is conducted by Computerized Automated Trading System and Chittagong Stock Exchange (CSE), established in 1995 which is also conducted by Computerized Automated Trading System. All exchanges are self-regulated, private sector entities which must have their operating rules approved by the Securities and Exchange Commission (SEC). As of 31 December 2006, the total issued capital of all listed securities of Dhaka Stock Exchange was TK 71,745 million (US\$1037 million) where as in Chittagong Stock Exchange the total issued capital was TK 68,554.72 million (US\$979.35 million). Total market capitalization of all securities listed with the Dhaka Stock Exchange was TK 3,23,368 million (US\$4673 million) as on 31 December 2006 compared to TK 2,67,480 million (US\$3821.14 million) in the Chittagong Stock Exchange.

\section{Literature review}

Initial public offerings (IPOs) are rapidly becoming one of the most thoroughly tackled topics in empirical finance. Early research related to initial public offerings (IPOs) documented the tendency of IPOs to provide abnormal returns to investors who purchased them at the initial offering (Stoll \& Curly, 1970). Refinements and extensions followed, including efforts to explain the variation in abnormal returns across firms and underwriters (Miller and Really, 1987). Information asymmetry, legal liability, and signaling theories have also been incorporated into IPO related research (Allen and Fauhaber, 1989; Baron, 1982; Rock, 1982; Tinic, 1988). 
The theory of efficient markets suggests that the price of the newly issued stock will quickly adjust to reflect the available set of relevant information (Fama, 1970). The persistence of underpricing has raised questions about what happens when firms go public. The decision to go public is one of the most important issues in corporate finance. Even in countries with developed capital markets like the United States, some large companies - such as United Parcel Service or Bechtel - are not public. In other countries, like Germany and Italy, publicly traded companies are the exception rather than the rule, and quite a few private companies are much larger than the average publicly traded companies. These cross-sectional and cross-country differences indicate that going public is not a stage that all the companies eventually reach, but is a choice, begging the question of why some companies choose to use public equity markets and some do not (Pagano et al., 1998). Basically, a firm enters the IPO market with two principal reasons (Rock, 1986). First, the founders of the firm may want to diversify their portfolios. The second reason is that the firm has no alternative source of funds to finance its investment project. Pagano et al., (1998) documented that a firm enters the IPO market for various reasons, including overcoming borrowing constraints, greater bargaining power with banks, liquidity and portfolio diversification, monitoring investor recognition, change of controls and windows of opportunity.

The price formation process for IPOs may be susceptible to the existence of significant conditional price trends in the short-run aftermarket for several reasons: first, there exists a growing body of literature noting that market reaction to the signals or news announcements issued by seasoned firms is not completed immediately (Agrawal, Jaffe, and Mandelkar, 1992). Instead, market prices adjust slowly to such news or signals, with trends extending over several months. IPOs are characterized by a great deal of uncertainty about their true value because of the scarcity of public information at the time of the initial offering. In such a noisy environment, judging the true value of a new issue is extremely difficult. Consequently, the initial return on an IPO (i.e., the difference between the first market price and the offer price) reveals significant information because it provides the first public indication that the market's average assessment of the IPO differs from that of the underwriter and the issuing firm. In addition, under the signaling theories (Allen and Faulhaber, 1989; Grinblatt and Hwang, 1989; and Welch, 1989) the initial market price provides a signal of the quality of the IPO.

Second, the first market price may fail to reflect fully all available information because of the potentially fragmented market for IPOs. The issue size of IPOs is typically small and the underwriters, often facing excess demand, ration new issues to their regular clients, who constitute a small subset of potential investors. Initial trading in the aftermarket serves to disseminate information about the value of IPOs to other investors. While initial upward price movement of underpriced IPOs spreads favorable information, the available supply of shares is restricted because underwriters typically discourage initial subscribers from selling their allotments in the aftermarket. Investors who were unable to obtain their full subscriptions at the offering may seek to buy shares in the aftermarket, resulting in a sequence of daily positive returns. In the case of an overpriced issue, the first market price fails to reflect the available information because of price stabilization by the underwriting syndicate. As the syndicates disband at varying times for the different IPOs, this leads to a gradual downward price adjustment on the average and sequential negative daily average cross-sectional returns over the short-run for overpriced IPOs. Such effects, however, may be offset by incentives provided by the syndicate to induce informed traders to reveal their private information while the offering price is being set. For example, in Benveniste and Spindt (1989) informed traders have an incentive to understate their interest in a new issue in the premarket, but underpricing induces them to be truthful in their indications of interest.

\subsection{Evidence from major stock exchanges}

A summary of average initial returns on IPOs across the major stock markets is shown in Table 2. (Table 2)

\subsection{Evidence from Asian stock exchanges}

The IPO behavior and after market performance have been examined by few researchers (Hoque and Musa, 2002; Islam, 1999 etc.) in Bangladesh context. The focus of these studies were primarily the underpricing and initial returns of IPOs, IPO flipping, market efficiency and effect of capital structures on the returns. Islam (1999) documented that the average initial returns is 116.01 percent with a standard deviation of 261.94 percent during the period between 1994-1999. Hoque and Musa (2002) find that during the period between 1994 and 2001, the IPOs of DSE was largely underpriced (285.21\%). A summary of average initial returns on IPOs across the major stock markets is shown in Table 3. (Table 3)

IPO underpricing - the phenomenon of a large positive gain to a new issue (relative to its offering price) immediately - after listing has been found in many markets. The magnitude of underpricing in China is even more phenomenal. Mok and Hui (1998) found that the underpricing A shares in Shanghai is 289\%. Su and Fleisher (1999) showed that the underpricing could exceed $948 \%$ if IPOs from earlier years were included in the sample. 


\subsection{Reasons for underpricing}

Much of the theoretical research on IPOs has focused on explaining IPO underpricing. Possible reasons for underpricing include self-interested investment bankers (Baron and Holmstrom, 1980; Baron, 1982), the "winner's curse" (Rock, 1986), lawsuit avoidance (Tinic, 1988), signaling (Allen and Faulhaber, 1989; Grinblatt and Hwang, 1989; Welch, 1989), market incompleteness (Mauer and Senbet, 1992), bookbuilding (Benveniste and Spindt, 1989), and informational cascades (Welch, 1992). Evidence also suggests that in some countries IPO underpricing may be due to the regulatory environment (Loughran, Ritter, and Rydqvist, 1994), or because the allocation of IPO shares can be used as a bribe. One possible explanation for the strong fluctuations in IPO volume is that the cost of issuing (Ibbotson and Ritter, 1995) for a survey of the research on initial public offerings. Attempts were made to examine the reasons for the initial high returns of these new issues. Some theoretical work suggests that the underpricing of IPOs is associated with asymmetric information and investors' concerns that the decision to issue equity is an attempt to expropriate wealth from outsiders (Ibbotson, 1994). Empirical studies have found evidence that the underpricing for IPOs of financial institutions is related to proxies for asymmetric information. Offer size (Megginson \& Weiss, 1991), age of the firm (Muscarella \& Vetsuypens, 1987; Barry \& Brown, 1994; Megginson \& Weiss, 1991; Logue, 1973; McDonald \& Fisher, 1972), and the volatility of the post-offer return (Ritter, 1984) have all been associated with IPO underpricing. Recently Taufil Mohd (2007) conducted empirical tests on the relationship between regulations and underpricing using 546 initial public offerings on the Kuala Lumpur Stock Exchange from 1990 to 2002 and finds that the length of time from price setting to listing date is negatively related to underpricing. However the fraction of shares set aside for indigenous investors and the concerns of ethnic associations that leads to lower offering prices do not seem to affect underpricing. Finally, it was found that the protective mechanisms lead to more underpricing for firms that went public between 1996 and November 6, 1997 or those that went public after the Asian financial crisis.

\section{Research methodology}

With regard to initial returns, underpricing for IPOs is a well-known phenomenon both in advanced markets in Western countries and also in emerging market such as Bangladesh. Studies on Dhaka Stock Exchange earlier documented higher degree of underpricing. Islam (1999) documented that the average initial returns is 116.01 percent with a standard deviation of 261.94 percent during the period between 1994-1999. In a recent study, Hoque and Musa (2002) find that during the period between 1994 and 2001, the IPOs of DSE was largely underpriced (285.21\%).

Attempts were made to examine the reasons for the initial high returns of these new issues. Offer size (Megginson \& Weiss, 1991), age of the firm (Muscarella \& Vetsuypens, 1987; Barry \& Brown, 1884; Megginson \& Weiss, 1991; Logue, 1973; McDonald \& Fisher, 1972; Balwinder Singh and Mittal, 2003), and the volatility of the post-offer return (Ritter, 1984) have all been associated with IPO underpricing. Recently, Taufil (2007) conducted empirical tests on the relationship between regulations and underpricing using 546 initial public offerings on the Kuala Lumpur Stock Exchange from 1990 to 2002 and finds that the length of time from price setting to listing date is negatively related to underpricing. Addition to these factors, the researcher expects size of the firm (as there is no division of main board and second board in Bangladesh) and the type of industry (as there is evidence of sectoral dominance among the listed firms) to be positively related to underpricing. Therefore, the following hypotheses are proposed:

\section{H1: IPOs listed with DSE are underpriced.}

H2: There is a positive relationship between age of firms and degree of Underpricing.

H3: The larger the size of offer, the lower the underpricing.

H4: There is a relationship between timing of offer and degree of underpricing.

H5: The larger the size of firm, the lower the underpricing.

H6: There is a significant difference between IPOs in different industry and degree of underpricing.

The underpricing/overpricing was measured by taking the difference of the closing price at the specific date in question with the offering price and divided by the offer price as shown below:

$$
\mathrm{R}_{\mathrm{j}, \mathrm{t}}=\left[\mathrm{P}_{\mathrm{j}, \mathrm{t}}-\mathrm{P}_{\mathrm{j}, 0}\right] / \mathrm{P}_{\mathrm{j}, 0}
$$

Where $R_{j}, t$ is the return of stock $j$ in the period $t, P_{j, t}$ is the price of stock $j$ at the period $t$, and $P_{j},{ }_{0}$ is the offer price of stock $\mathrm{j}$. Returns was measured with $\mathrm{P}_{\mathrm{j}, 0}$ using the opening price to determine the return for investors who were unable to buy the stock when it was offered but bought it on the opening day. 
Multiple regression was employed to find out factors that significantly affect underpricing at Bangladesh capital market. The model is described below:

$\mathrm{UND}=\alpha_{0}+\alpha_{1} \mathrm{AOF}+\alpha_{2} \mathrm{SOF}+\alpha_{3} \mathrm{SOFF}+\alpha_{4} \mathrm{TIME}+\alpha_{5} \mathrm{TYPE}+\varepsilon$

Where

$\mathrm{UND}=$ Underpricing/Overpricing, $\mathrm{AOF}=$ Age of the firm, $\mathrm{SOF}=$ Size of the firm, $\mathrm{SOFF}=$ Size of the offer, TIME $=$ Timing of the offer, and TYPE = Type of industry

Age of the firm was computed from the date of incorporation to the date of IPO (David, 2002). The company size was measured by using the net assets of the company in the year of IPO as done by Khurshid, Mudambi and Georgen (1999). Timing of offer was measured by Balwinder Singh and Mittal, (2003) and Taufil (2007) as the time taken from the date of listing to the offer date.

This study examined new companies, which were listed on the CSE for the period 1995-2005. All the data used in this study will be secondary data gathered from: Prospectuses, CSE Daily Diaries, CSE and SEC websites, and Annual Report of listed Companies. The population of this study includes all listed companies in the CSE. This study includes IPO issuers in all sectors such as Financial sector that include Bank, Insurance and Investment; Manufacturing sector that include Cement, Engineering, Ceramics, Food and Allied products, Jute, Paper and Printing, Pharmaceuticals and Chemicals, Tannery Industry and Textiles. Finally Service \& miscellaneous that include Fuel and Power, IT, Services and Real Estates, and Miscellaneous. The objective of this study is to gauge the new issue stock price behavior in IPO firms as listed in the CSE. This research also serves to examine the determinants of underpricing in the Chittagong Stock Exchange.

\section{Results}

The sample data is consisted of companies that are listed into CSE between the periods of 1995 to 2005. Table 4 presents the sample profile of listed companies in the sample period at CSE. (Table 4)

Table 4 shows that the highest number of companies that were listed with the Chittagong Stock Exchange was from the financial sector. There were 53 companies listed during this period. Financial sector includes Banks, Insurance, finance, leasing and investment companies. The next highest number of companies that were listed with CSE was from tannery and textile companies. Tannery and textile companies include textiles, spinning, leather and foot wears. There were 40 companies listed in the CSE during this period. The $3^{\text {rd }}$ largest sector was manufacturing. There were 28 companies listed during the sample period into the CSE. The next highest contributing listing was from the Miscellaneous. There were 27 companies listed with CSE from this sector during this period. The lowest number of companies that were listed in the CSE during the sample period was paper and printing sector. There were only six companies listed during this period.

There were 51 companies listed during the year 1995. This is the year the Chittagong Stock Exchange was launched. The next highest listing was in 1996. There were 49 companies listed with CSE during this year. The next highest contributing year in terms listing was 1997. There were 18 companies listed during this year. After that the number of companies listed with the Chittagong Stock Exchange at the average rate of 10 companies a year. The lowest number of companies listed in the year 1998. There were only five companies listed in this year in the Chittagong Stock Exchange.

\subsection{Level of underpricing/overpricing}

This section presents the level of underpricing and overpricing in the Chittagong Stock Exchange. The overall level of underpricing at the Chittagong Stock Exchange was $480.72 \%$ with a standard deviation of 1217.25 . There were 173 (90.57\%) IPOs underpriced and only 16 (8.37\%) were overpriced. The overall level of overpricing was $17.87 \%$ with a standard deviation of 14.14 . There were only two (1.04\%) IPOs where the $1^{\text {st }}$ day opening prices were same as the issue price. Table 5 presents the overall level of underpricing/overpricing at the Chittagong Stock Exchange. (Table 5)

The maximum level of underpricing at CSE was $11900 \%$ and minimum level of underpricing was $1 \%$. The maximum level of overpricing at DSE was $50 \%$ whereby the minimum level of overpricing was $2 \%$.

\subsubsection{IPO underpricing on yearly basis}

The highest degree of underpricing at the Chittagong Stock Exchange was registered in the year 1996 (1006.69\% with a standard deviation of $2053.05 \%$ ). There were 20 companies listed in this year. The next highest level of underpricing was recorded in the year 1995 (490.41\% with a standard deviation of 905.10). There were 48 companies listed with DSE in this year. The CSE was launched in this year. The $3^{\text {rd }}$ highest level of IPO underpricing at DSE was recorded in the year 2004 (438.76\% with a standard deviation of 466.36). There were 11 
companies listed in this year. The next highest level of underpricing recorded in the year 2005 which recorded underpricing of $290.40 \% \%$ with a standard deviation of 190.44 . Table 6 presents the IPO underpricing on a yearly basis among CSE listed companies. (Table 6)

The lowest number of underpricing recorded in the year 1998. The level of underpricing was $11.33 \%$ with a standard deviation of 7.77 .

\subsubsection{IPO overpricing on yearly basis}

The highest level of overpricing recorded at the Chittagong Stock Exchange in the year $2003(32.50 \%$ with a standard deviation of 24.75). There were two IPOs (16.67\%) overpriced in this year out of twelve companies listed at DSE. The second highest number of IPOs that were overpriced was the year $1996(32.00 \%$ with a standard deviation of 11.31). There were two (11\%) companies out of twenty two companies listed into CSE in this year. The lowest level of overpricing recorded in the year 2004 (4\%).

\subsubsection{IPO underpricing on industry basis}

The highest level of underpricing recorded at the Chittagong Stock Exchange was the manufacturing sector (971.84\% with a standard deviation of 2207.36). There were forty seven companies underpriced from this sector. The next highest level of underpricing registered in the Food and allied products sector $(639.77 \% \%$ with a standard deviation of 1373.83). There were 18 companies underpriced from this sector. The services and miscellaneous sector recorded the next highest level of underpricing (583.99\% with a standard deviation of 1291.95$)$. There were 23 IPOs listed in this sector during the sample period. The lowest level of underpricing recorded in the paper and printing sector (180.83\% with a standard deviation of 306.15). Tannery and textiles sector recorded the next lowest level of underpeicing (225.71\% with standard deviation of 404.90). There were 34 IPOs underpriced in this sector. (Table 7)

\subsubsection{IPO overpricing on industry basis}

The highest level of overpricing at the Chittagong Stock Exchange recorded in the food and allied products sector $(25.50 \%$ with a standard deviation of 10.61$)$. There were two companies overpriced in this sector during sample period. The highest number of companies overpriced recorded in the financial sector. There were five $(12.19 \%)$ companies overpriced in this sector out of 41 listed companies. The lowest level of overpricing was recorded in the pharmaceuticals and chemical sector (5\%). There was only one (5.88\%) IPO overpriced out of 17 listed IPOs. There were no overpriced IPOs in the manufacturing sector during the sample period.

\subsubsection{Determinants of underpricing}

Multiple Regression analysis was used to find out whether offer size, size of the company, years of operation before listing, timing of offer and sector have any significant effect on the degree of underpricing or overpricing at Chittagong Stock Exchange. Table 8 presents the results of regression analysis. (Table 8)

Based on the regression analysis results offer size is found to be significant with a negative beta at $5 \%$ significance level (sig $\mathrm{t}=.000)$. This indicates that offer size has significant negative effect on the degree of underpring at the Dhaka Stock Exchange. Therefore hypothesis 3 on Chittagong Stock Exchange is substantiated.

Size of the company is found to be significant at $5 \%$ significance level $(\operatorname{Sig} t=.017)$ with a positive beta. This means that size of the company positively influences the degree of underpricing at Dhaka Stock Exchange. Therefore Hypothesis 5 is accepted. Dummy variables were created for sectors that companies are listed at Chittagong Stock Exchange because it was a categorical variable. Six dummies were created for CSE sectors. Regression analysis results show that the sector that a company belongs to has significant effect on the degree of underpricing at 5\% significance level. Therefore hypothesis 6 is substantiated.

Years of operation before listing into the CSE were also found to have a significant effect $(\mathrm{Sig} t=.020)$ on the degree of underpricing at Chittagong Stock Exchange. Therefore hypothesis 2 was accepted. Timing of offer was found to have no significant effect on the degree of underpricing at the CSE. Therefore hypothesis 4 was not substantiated.

The R square was $32.8 \%$. This means that age of the firm, timing of offer, offer size, size of the company and sector that a company listed into can explain 32.8\% variations of the degree of underpricing at the Dhaka Stock Exchange. This indicates that there are other factors that may explain $67.2 \%$ variations of the degree of underpricing at the Dhaka Stock Exchange. Initially the R square was low due to the outliers. Outliers were then taken out and R square increased significantly. The Durbin-Watson falls within the acceptable range (1.542). Therefore there was no serial correlation problem in the data. The VIF $(1-10)$, tolerance $(0.1-1)$ and the condition index (7.029) all fell into the acceptable range. Hence there was no multicolleniarity problem in the regression model. The histogram shows that data were normally distributed. Scatter plot shows that data were not concentrated and therefore there was no 
homoscedasticity in the data. Normal P-P plot shows that the data were linear. The F-value was large (3.850) and found to be significant at $1 \%$ significance level $(\mathrm{Sig} F=.000)$. These all construct that the regression model used for the analysis was fit or in another word there was an adequate model.

\section{Conclusion}

The degree of underpricing in the Bangladesh capital market is rather high compared to that of other Asian and advanced stock markets. Islam M.S. (1999) documented that the average initial returns is 116.01 percent with a standard deviation of 261.94 percent during the period between 1994-1999. Hoque and Musa (2002) find that during the period between 1994 and 2001, the IPOs of DSE was largely underpriced at 285.21 percent. At the same period the degree of underpricing in Malaysia was $46.44 \%$ (Yeap, M. 2006), Singapore and Turkey were $31.4 \%$ and $13.6 \%$ respectively (Laughran et al., 2000), India was 96.56\% (Balwilder Singh and RK Mittal., 2003) and in US market was $22 \%$ (Lowry et al., 2006). Our findings are consistent with earlier findings of Hoque and Musa (2002) and Islam M.S. (1999). Out of the 117 companies that were listed in the years 1995 to 2005, $102(87.18 \%)$ IPOs were found to be underpriced, $13(11.11 \%)$ overpriced while only 2 were accurately priced. The overall level of underpricing was $480.71 \%$ with a standard deviation of 1217.24 . This is considered very high as compared to other stock exchanges and the Dhaka stock exchange as well. This could be due the fact that the study sample data taken from inaugural year to subsequent nine years. The overall level of overpricing was $17.87 \%$ with a standard deviation of 14.14. The high degree of underpricing is still persistent. In order to reduce the persistent higher degree of underpricing the Securities and Exchange Commission should review the fixed pricing system. It is recommended that Book building pricing be implemented to reduce the persistent higher degree of underpricing. Regression Analysis shows that age of the firm and size of the company is positively related to the degree of underpricing. The industry type and the offer size are found to be negatively related to the degree of underpricing. However timing of offer was found to have no significant influence on the degree of underpricing of IPOs in the Chittagong Stock Exchange. The finding on the industry type affects on degree of underpricing is somewhat new and therefore it contributes to body of existing knowledge.

\section{References}

Aggarwal, R. \& Rivoli, P. (1990). Fads in the initial public offering market? Financial Management, 19(4). 45.

Allen, F. \& Faulhaber, G.R. (1989). Signaling by underpricing in the IPO market. Journal of Financial Economics, 23, 303-323.

Balwinder S. \& Mittal, P.K. (2003). Underpricing of IPOs: Indian experience. The ICFAI Journal of Applied Finance, 9(2). 29.

Baron, D. P. (1982). A Model of the demand for investment banking advising and distribution services for new issues. Journal of Finance, 37, 955-976.

Baron, D.P. \& Holmstrom, B. (1980). The investment banking contract for new issues under asymmetric information: Delegation and the incentive problem. Journal of Finance, 35, 1115-1138.

Barry, C.B. \& Brown, S. (1985). Differential information and security market equilibrium. Journal of Financial Quantitative Analysis, 20, 407-422.

Barry, C.B. \& Jennings, R.H. (1993). The opening price performance of initial public offerings of common stock. Financial Management, 22(1).

Beatty, R.P. \& Ritter, J.R. (1986). Investment banking reputation and underpricing of initial public offerings. Journal of Financial Economics, 15, 213-232.

Benveniste, L.M. \& Spindt, P.A. (1989). How investment bankers determine the offer price and allocation of new issues. Journal of Financial Economics, 24, 343-361.

Chan, K., Wang, J. \& Wei, K.C. (2003). Underpricing and long-term performance of IPOs in China. Journal of Applied Corporate Finance, 1-22.

Clerk, D.T. (2002). A study of the relationship between firm age - at - IPO and the aftermarket stock performance, working paper, School of Business, Gluckswan Institution for Research.

Steven, D.M. (1987a). Secondary stock market performance of initial public offers: Hong Kong, Singapore and Malaysia. Journal of Business Finance \& Accounting, 65-76.

Steven, D.M. (1987b). Initial Public Offer Underpricing: The Issuer's View - A Note. Journal of Finance, 42(1). 159-162.

Grinblatt, M. \& Hwang, C.Y. (1989). Signalling and the Pricing of New Issues. Journal of Finance, 44, 393-420. 
Hoque, M. \& Musa, M. (2002). The long run performance of IPOs in Bangladesh. Journal of Business Administration, University of Dhaka, 27(1 \& 2).

Ibbotson, R.G. \& Ritter, J.R. (1995). Initial Public Offerings, in: Finance (R.A.Jarrow, V. Maksimovi,c, and W.T. Ziemba, Eds.) pp. 993-1016. Elsevier, Amsterdam.

Islam, M. S. (1999). The behavior of IPO underpricing in Bangladesh. Journal of Finance and Banking, 5(1 \& 2).

Ismail, K.N.I.K., Abidin F.Z. \& Zainuddin, N. (1993). Performance of New Stock Issues on the KLSE. Capital Market Review, 1(1). 81-95.

Loughran, T. \& Ritter J.R. (1995). The New Issues Puzzle. The Journal of Finance, 50(1). 23-51.

Loughran, T., Ritter J.R.\& Rydqvist, K. (1994). Initial Public Offerings: International Insights, Pacific-Basin Finance Journal, 2, 165-199.

Loughran, T. \& Ritter, J.R. (2004). Why has IPO underpricing changed over time? Financial Management, 33, 5-37.

Lowry, M. \& Schwert, G.W. (2004). Is the IPO pricing process efficient? Journal of Financial Economics, 71, 3-26.

Lowry, M., Officer, M.S. \& Schwert, G.W. (2006). The Variability of IPO Initial Returns. Working Paper, University of Southern California, Los Angeles, CA 90089.

Mauer, D. C. \& Senbet, L.W. (1992). The Effect of the Secondary Market on the Pricing of Initial Public Offerings: Theory and Evidence. Journal of Financial and Quantitative Analysis, 24, 55-79.

Hassan, M.K., Islam, A.M. \& Basher, S.A. (2000). Market Efficiency, Time-Varying Volatility and Equity Returns in Bangladesh Stock Market, Working paper, University of New Orleans.

McDonald, J.G. \& Fisher, A.K. (1972). New Issues Stock Price Behavior. Journal of Finance, 97-102.

McGuiness, P. (1992). An Examination of the Underpricing of Initial Public Offerings in Hong Kong: 1980-1990, Journal of Business Finance and Accounting 19(2). January, pp. 165-186.

McStay, K. (1992). The Efficiency of New Issues Markets. NY: Garland Publishing, Inc.

Megginson, W.L., \& Weiss, K.A. (1991). Venture capitalist certification in initial public offerings. Journal of Finance, 46, 879-903.

Miller, R.E. \& Reilly, F.K. (1987). An Examination of Mispricing, Returns and Uncertainty for Initial Public Offerings. Financial Management, 33-38.

Mok. H.M. \& Hui, Y.V. (1998). Underpricing and the aftermarket performance of IPOs in Shanhai, China. Pacific-Basin Finance Journa, 6, 453 - 474.

Muscarella, C.J. \& Vetsuypens, M.R. (1989). A simple test of Baron's model of IPO underpricing. Journal of Financial Economics, 24, 125-135.

Pagano, M., Fabio, P. \& Luigi, Z. (1998). Why do companies go public? An empirical analysis. Journal of Finance, 53(1).

Reilly, F.K. (1973). Further evidence on short-run results for new issue investors. Journal of Financial and Quantitative Analysis, 8, 83-90.

Ritter, J.R. (1984). Signaling and the Evaluation of Unseasoned New Issues: A Comment. The Journal of Finance, 39, 1231-1237.

Ritter, J.R. (1991). The Long Run Performance of Initial Public Offerings. The Journal of Finance, 46, 3-27.

Rock, K. (1986). Why New Issue are Under Priced. Journal of Financial Economics, 15, 187-212.

Sufar, S. B. (1987). Performance of new issues - the Malaysian case, Understanding the behavioral patterns of stock prices,_Leeds Publications, pp. 164-171.

Stoll, H.R. \& Curley, A.J. (1970). Small Business and the New Issues Market for Equities. Journal of Financial and Quantitative Analysis, September, 309-322.

Su, D.W. \& Fleisher, B. (1999). En Empirical Investigation of Underpricing in Chinese IPOs. Pacific-Basin Finance Journal, 7, 173-202.

Taufil, M.K.N. (2007). The long run performance of initial public offerings in Malaysia. The MFA $9^{\text {th }}$ Conference, $12-13^{\text {th }}$ June, Kuala Lumpur. 
Tinic, S.M. (1998). Anatomy of IPOs of Common Stock. The Journal of Finance, 43(4). 789-822.

Welch, I. (1989). Seasoned Offerings, Imitation Costs, and the Underpricing of Initial Public Offerings. Journal of Finance, 44, 421-449.

Yeap, M. (2006). An empirical investigation into the underpricing of IPOs in the new millennium in Malaysia, an unpublished MBA thesis, Nottingham Trent University, UK.

Yong, O. (1991). Performance of New Issues of Securities in Malaysia. Malaysian Accountant, June, 3-6.

Yong, O. (1996). Who actually did gain from the underpricing of IPOs, Capital Markets Review, 4(1). 33-47.

Table 1. Market capital as percentage of GDP (As of December 2006)

\begin{tabular}{|l|r|r|r|}
\hline \multicolumn{1}{|c|}{ Country } & \multicolumn{1}{c|}{ GDP size } & Market capital of the listed stocks & \multicolumn{1}{c|}{ Market capital as percentage of GDP } \\
\hline Indonesia & $\$ 353.00 \mathrm{~b}$ & $\$ 134.00 \mathrm{~b}$ & $38.0 \%$ \\
\hline Pakistan & $\$ 127.00 \mathrm{~b}$ & $\$ 48.00 \mathrm{~b}$ & $41.0 \%$ \\
\hline Philippines & $\$ 117.00 \mathrm{~b}$ & $\$ 73.70 \mathrm{~b}$ & $63.0 \%$ \\
\hline South Korea & $\$ 886.00 \mathrm{~b}$ & $\$ 824.00 \mathrm{~b}$ & $93.0 \%$ \\
\hline Malaysia & $\$ 150.00 \mathrm{~b}$ & $\$ 160.00 \mathrm{~b}$ & $106.67 \%$ \\
\hline India & $\$ 750.00 \mathrm{~b}$ & $\$ 810.00$ & $108.0 \%$ \\
\hline Bangladesh & $\$ 62.02 \mathrm{~b}$ & $\$ 8.47 \mathrm{~b}$ & $15.0 \%$ \\
\hline Iran & $\$ 182.00 \mathrm{~b}$ & $\$ 38.30 \mathrm{~b}$ & $21.0 \%$ \\
\hline Vietnam & $\$ 61.00 \mathrm{~b}$ & $\$ 14.00 \mathrm{~b}$ & $23.0 \%$ \\
\hline
\end{tabular}

Source: www.devdata.worldbank.org

Table 2. Average initial returns in major stock markets

\begin{tabular}{|l|l|c|c|c|}
\hline Country & Researcher & Sample size & Time period & Average initial return \\
\hline Australia & Lee, Taylor and Walter; Woo & 381 & $1976-1995$ & $12.1 \%$ \\
\hline Austria & Aussenegg & 76 & $1984-1999$ & $6.5 \%$ \\
\hline Belgium & Rogiers, Manigard and Ooghe & 28 & $1984-1990$ & $10.1 \%$ \\
\hline Brazil & Aggarwal, Leal and Hernandex; Maturana & 62 & $1979-1990$ & $78.5 \%$ \\
\hline Canada & Job and Riding; Jog and Srivastava & 258 & $1971-1992$ & $5.4 \%$ \\
\hline Chile & Aggarwal, Leal and Hernandex; Maturana & 55 & $1982-1997$ & $8.8 \%$ \\
\hline Denmark & Jakobsen and Sorenson & 117 & $1984-1998$ & $6.4 \%$ \\
\hline Finland & Keloharju & 85 & $1984-1992$ & $9.6 \%$ \\
\hline France & Husson and Jacquillat; Leleux and Muzyka; & 187 & $1983-1992$ & $4.2 \%$ \\
\hline Germany & Lallard and Belletante & & & $27.7 \%$ \\
\hline Greece & Kazantzis and Levis & 407 & $1978-1999$ & $48.5 \%$ \\
\hline Israel & Kandel, Sarig and Wohl & 79 & $1987-1991$ & $4.5 \%$ \\
\hline Italy & Cherubini and Ratt; Giudici and Paleari & 28 & $1993-1994$ & $20.3 \%$ \\
\hline Mexico & Aggarwal, Leal and Hernandex & 135 & $1985-1998$ & $33 \%$ \\
\hline Netherlands & Wessels; Jenkinson & 37 & $1987-1990$ & $10.2 \%$ \\
\hline New Zealand & Vos and Cheung; Camp & 143 & $1982-1999$ & $23 \%$ \\
\hline Nigeria & Ikoku & 201 & $1979-1999$ & $19.1 \%$ \\
\hline Norway & Emilsen, Paderson and Saettern & 63 & $1989-1993$ & $12.5 \%$ \\
\hline Poland & Aussenegg & 68 & $1984-1996$ & $35.6 \%$ \\
\hline Portugal & Alpalhao & 149 & $1991-1998$ & $54.4 \%$ \\
\hline Spain & Rahnema and Fernandex & $1986-1987$ & $35 \%$ \\
\hline Sweeden & Rydqvist & $1985-1990$ & $34.1 \%$ \\
\hline Switzerland & Kunz and Aggarwal & $1980-1994$ & $1983-1989$ & \\
\hline
\end{tabular}

Source: Loughran et al (2000) 
Table 3. Average initial returns in Asian stock markets

\begin{tabular}{|l|l|c|c|c|}
\hline \multirow{3}{*}{ Bangladesh } & Researcher & Sample size & Time period & Average initial return \\
\cline { 2 - 5 } & Mohammad Sadequl Islam & 95 & $1994-1999$ & $116.01 \%$ \\
\cline { 2 - 5 } & Hoque and Musa & 113 & $1994-2001$ & $285.21 \%$ \\
\cline { 2 - 5 } & Datar and Mao & 226 & $1990-1996$ & $388 \%$ \\
\cline { 2 - 5 } & Chan et al & 701 & $1992-1997$ & $145 \%$ \\
\hline \multirow{2}{*}{ Inong Kong } & McGuiness; Chao and Wu & 334 & $1980-1996$ & $15.9 \%$ \\
\cline { 2 - 5 } & Krishnamurti and Kumar & 98 & $1992-1993$ & $35.3 \%$ \\
\hline \multirow{2}{*}{ Japan } & Balwilder Singh and RK Mittal & 500 & $1992-1996$ & $96.56 \%$ \\
\hline Korea & Fukuda; Dawson and Hiraki & 975 & $1970-1996$ & $24 \%$ \\
\hline \multirow{2}{*}{ Malaysia } & Jhatt, Kim and Lim & 347 & $1980-1990$ & $78.1 \%$ \\
\cline { 2 - 5 } & Isa and Yong & 401 & $1980-1998$ & $104.1 \%$ \\
\hline Philippines & Mellisa yeap & 323 & $2000-2005$ & $46.44 \%$ \\
\hline Singapore & Leep, Taylor and Walter & 104 & $1987-1997$ & $22.7 \%$ \\
\hline Taiwan & Lin and Sheu & 128 & $1973-1992$ & $31.4 \%$ \\
\hline Thailand & Wethyavivorn and Koo-Smith & 241 & $1986-1995$ & $34.6 \%$ \\
\hline Turkey & Kiymaz & 138 & $1988-1989$ & $58.1 \%$ \\
\hline
\end{tabular}

Table 4. New issues on an industry to industry basis

\begin{tabular}{|l|c|c|c|c|c|c|c|c|c|c|c|c|}
\hline Sector & 1995 & 1996 & 1997 & 1998 & 1999 & 2000 & 2001 & 2002 & 2003 & 2004 & 2005 & Total \\
\hline Financial & 14 & 09 & 03 & 01 & 00 & 04 & 03 & 00 & 04 & 09 & 06 & 53 \\
\hline Manufacturing & 05 & 12 & 03 & 02 & 02 & 01 & 00 & 02 & 01 & 00 & 00 & 28 \\
\hline Food and allied Products & 04 & 06 & 02 & 02 & 00 & 01 & 03 & 02 & 00 & 00 & 00 & 20 \\
\hline Paper and Printing & 00 & 01 & 01 & 00 & 02 & 01 & 01 & 00 & 00 & 00 & 00 & 06 \\
\hline Pharmaceutical and Chemicals & 06 & 04 & 03 & 00 & 00 & 00 & 01 & 01 & 01 & 00 & 01 & 17 \\
\hline Tannery and Textiles & 15 & 12 & 04 & 00 & 03 & 01 & 02 & 02 & 00 & 01 & 00 & 40 \\
\hline Services and Misc. & 07 & 05 & 02 & 00 & 01 & 00 & 02 & 01 & 06 & 02 & 01 & 27 \\
\hline Total & $\mathbf{5 1}$ & $\mathbf{4 9}$ & $\mathbf{1 8}$ & $\mathbf{0 5}$ & $\mathbf{0 9}$ & $\mathbf{0 8}$ & $\mathbf{1 2}$ & $\mathbf{0 8}$ & $\mathbf{1 2}$ & $\mathbf{1 2}$ & $\mathbf{0 8}$ & $\mathbf{1 9 1}$ \\
\hline
\end{tabular}

Table 5. Overall levels of IPO underpricing and overpricing

\begin{tabular}{|l|c|c|c|c|c|}
\hline & $\begin{array}{c}\text { Number of } \\
\text { companies }\end{array}$ & $\begin{array}{c}\text { Mean Level of } \\
\text { Underpricing }\end{array}$ & Maximum & $\begin{array}{c}\text { Minimu } \\
\mathrm{m}\end{array}$ & $\begin{array}{c}\text { Standard } \\
\text { Deviation }\end{array}$ \\
\hline Underpricing & 173 & 480.7126 & 11900.00 & 1.00 & 1217.24466 \\
\hline Overpricing & 16 & 17.8750 & -2.00 & -50.00 & 14.13683 \\
\hline Similar Pricing & 02 & 0.00 & 0.00 & 0.00 & 0.00 \\
\hline Total & $\mathbf{1 9 1}$ & $\mathbf{4 3 3 . 9 1 2 5}$ & $\mathbf{1 1 9 0 0 . 0 0}$ & $\mathbf{- 5 0 . 0 0}$ & $\mathbf{1 1 6 7 . 2 5 9 5}$ \\
\hline
\end{tabular}

Table 6. IPO underpricing on a yearly Basis

\begin{tabular}{|l|c|c|c|c|c|}
\hline Year & $\begin{array}{l}\text { Number of } \\
\text { Companies }\end{array}$ & $\begin{array}{l}\text { Mean Level of } \\
\text { Underpricing }\end{array}$ & Standard Deviation & Maximum & Minimum \\
\hline 1995 & 48 & 490.4167 & 905.09892 & 5100.00 & 2.00 \\
\hline 1996 & 20 & 1006.6957 & 2053.04872 & 11900.00 & 5.00 \\
\hline 1997 & 17 & 172.7059 & 260.75006 & 950.00 & 3.00 \\
\hline 1998 & 03 & 11.3333 & 7.76745 & 20.00 & 5.00 \\
\hline 1999 & 06 & 135.0000 & 172.29510 & 480.00 & 30.00 \\
\hline 2000 & 08 & 167.6250 & 417.28132 & 1200.00 & 1.00 \\
\hline 2001 & 11 & 84.3409 & 91.61688 & 290.00 & 9.00 \\
\hline 2002 & 07 & 46.5714 & 43.48891 & 113.00 & 1.00 \\
\hline 2003 & 10 & 37.1750 & 29.13476 & 96.25 & 1.00 \\
\hline 2004 & 11 & 438.7640 & 466.36044 & 1500.00 & 10.00 \\
\hline 2005 & 06 & 290.3968 & 190.44149 & 560.00 & 38.42 \\
\hline 2006 & 10 & 141.3767 & 98.54854 & 372.00 & 60.00 \\
\hline 2007 & 14 & 281.0000 & 212.16189 & 695.00 & 18.00 \\
\hline
\end{tabular}


Table 7. IPO underpricing on an industry basis

\begin{tabular}{|l|c|c|c|c|c|}
\hline Industry & $\begin{array}{c}\text { Number of } \\
\text { Companies }\end{array}$ & $\begin{array}{c}\text { Mean Level of } \\
\text { Underpricing }\end{array}$ & $\begin{array}{c}\text { Standard } \\
\text { Deviation }\end{array}$ & Maximum & Minimum \\
\hline Financial & 47 & 324.6246 & 842.48633 & 5800.00 & 1.00 \\
\hline Manufacturing & 28 & 971.8393 & 2207.36307 & 11900.00 & 1.00 \\
\hline Food and Allied Products & 18 & 639.7778 & 1373.82624 & 5100.00 & 10.00 \\
\hline Paper and Printing & 06 & 180.83333 & 306.15252 & 800.00 & 9.00 \\
\hline Pharmaceutical and Chemicals & 16 & 433.5885 & 540.81152 & 1810.00 & 1.00 \\
\hline Tannery and Textiles & 34 & 225.7132 & 404.90114 & 1595.00 & 3.00 \\
\hline Services and Misc. & 23 & 583.9876 & 1291.94616 & 6000.00 & 2.00 \\
\hline Total & $\mathbf{1 7 3}$ & $\mathbf{4 8 0 . 7 1 2 6}$ & $\mathbf{1 2 1 7 . 2 4 4 6 6}$ & $\mathbf{1 1 9 0 0 . 0 0}$ & $\mathbf{1 . 0 0}$ \\
\hline
\end{tabular}

Table 8. Results of regression analysis (determinants of underpricing)

\begin{tabular}{|c|c|c|c|}
\hline Factors & Beta & T-Ratio & Sig t \\
\hline Years of Operations before listing & .189 & 2.341 & .020 \\
\hline Offer Size & -.262 & -3.852 & .000 \\
\hline Size of the company & .183 & 2.418 & .017 \\
\hline Timing of offer & .065 & .974 & .331 \\
\hline Dummy_Com1 & .420 & 5.184 & .000 \\
\hline Dummy_Com2 & -.088 & -1.071 & .286 \\
\hline Dummy_Com3 & .051 & .716 & .475 \\
\hline Dummy_Com4 & .041 & .511 & .610 \\
\hline Dummy_Com5 & -.121 & -1.272 & .205 \\
\hline Dummy_Com6 & .011 & .132 & .895 \\
\hline \multicolumn{4}{|c|}{ R Square $=32.8 \%$} \\
\hline \multicolumn{4}{|c|}{ Adjusted R Square $=28.7 \%$} \\
\hline \multicolumn{4}{|c|}{ Durbin-Watson $=1.542$} \\
\hline \multicolumn{4}{|c|}{$\mathrm{F}=8.093, \operatorname{Sig} \mathrm{F}=.000$} \\
\hline \multicolumn{4}{|c|}{ Condition Index $=7.029$} \\
\hline
\end{tabular}

